\title{
Transformation of Agricultural Land for Urbanisation, Infrastructural Development and Question of Future Food Security: Cases from Parts of Hugli District, West Bengal
}

Dr. Giyasuddin Siddique ${ }^{\dagger}$ and Nabanita Mukherjee ${ }^{\iota^{*}}$

\section{Abstract}

Developing countries of the world encounter urbanisation and infrastructural development in or around the fertile tracts and the absence of any landuse plan for desired landuse change has led to conversion of farmlands, which is detrimental to future food security and environmental quality. Hugli district is traditionally well known as one of the most prosperous agricultural regions of West Bengal, but the district is experiencing rapid urban extension and infrastructural development towards productive agricultural land since 1991. This has caused decline in the amount of agricultural production, which may be treated as an indicator of increasing threat to the long run sustainable livelihood security of the people of the whole of West Bengal. This article critically explores the transformation of agricultural (farm) land because of growing rate of urbanisation and infrastructural development, which in turn poses the question of threat to food (in) security. Although, this is a growing problem across the universe, this article probes the future food security questions of Hugli district, West Bengal by examining the impact of the highly intertwined indicators of urbanisation and infrastructural development on agricultural (farm) landuse and its effect on food security. Regression Analysis, Spearman's Ranking Correlation Coefficient, Remote Sensing Technologies, Markov Chain Model, Projection of Future Population Growth, and Yield Rate are employed to understand the depth of the problem. The result not only shows a direct negative correlation between urban extension and agricultural areal contraction but also the supervised classification of satellite imageries shows that there is rapid change of rural landuse from 1996-2016. There is no match between future population growth and future yield rate of crops and the Markov Chain Model further predicts that the cropland will decrease from $62.77 \%$ to $42.90 \%$ and the built up area will increase from $31.86 \%$ to $54.63 \%$ of the total area from 2016 to 2056.

Keywords: Urbanisation, Infrastructural Development, Landuse Change, Food Security, Sustainable Livelihood, Markov Chain Model, Hugli District, West Bengal

\footnotetext{
${ }^{\dagger}$ Professor and Head, Department of Geography, The University of Burdwan, West Bengal, Email: gsbu2008@gmail.com Corresponding Author

IUGC-Junior Research Fellow, Department of Geography, The University of Burdwan, Email: nabanita.mkj@gmail.com (C) 2017 Siddique and Mukherjee. This is an Open Access article distributed under the terms of the Creative Commons Attribution License (http://creativecommons.org/licenses/by/2.0), which permits unrestricted use, distribution, and reproduction in any medium, provided the original work is properly cited.
} 


\section{Introduction}

Urbanisation, as already well established, is the shift from a rural to an urban society and involves an increase in the number of individuals living in urban areas within a specified time (Adesegun et al., 2015; Omer, 2016). It is the result of social, economic and political advancement that lead to urban concentration and emergence of large cities, change in landuse and transformation of pattern of organisation and governance from rustic to metropolitan system (Ekpenyong, 2015:31) through the development of different forms of infrastructure. The term 'infrastructure' is coined by joining 'infra' and 'structure', which means subordinate parts, substructure or establishment of an endeavour (Nayak, 1999: 59). According to the economists of the world, it contains of all those amenities and activities, the basic rationale of which is the sustenance, which they provide to income generation and production (Bajpai, 1995). Infrastructures are the very heart of financial and social advancement. There are two aspects of infrastructure, on one hand, they boost economic growth, address basic needs, offer mobility and social interaction, and on the other hand, they generate environmental pressure (Shilling, 2007: 1). In most cases, infrastructural development cause transformation of agricultural land, thus both urbanisation and infrastructural development can be treated as a growing threat to food security. 'Food security' has been described by the FAO (Food and Agriculture Organisation) in its World Food Summit in 1996: "food security exists when all people, at all times, have physical and economic access to sufficient, safe, nutritious food to meet their dietary needs and food preferences for an active and healthy life" (FAO, 2008: 1). The organisation has recognised four key dimensions of food securityavailability, stability, safety and access to food. The first measurement is related to the general availability of food in adequate amount. Both production and supply system of food are distinctive in rustic and urban setting. Food stability alludes to the access to food at all times with no danger of losing access as a consequence of sudden stuns, for example economic or climatic crises or cyclical events such as agricultural seasons. Food safety is connected to the quality of food and the final dimension, access to food is related with the assets that people or their families possesses to obtain food necessitated for a healthy living (FAO, 2008:1). Thus for people living in urban zones, access to food is consequent upon the household's ability to purchase food. Each of these four key facets of food security can be studied in the milieu of urban environment. The decadal growth of population of the study area is $10.59 \%$, the decadal growth of urban population is $42.13 \%$ and meeting the demand of such a large population will put enormous additional pressure on food production system, because the resources required for its production such as land and water are becoming meagre. The following section discusses literature that underpins this research.

\section{Review of Literature}

Ira Matuschke (2009) in the paper titled 'Rapid Urbanisation and Food Security: Using Food Density Maps to Identify Future Food Security Hotspots' explained the challenges of rapid urbanisation in developing countries and the impact of rapid urbanisation on four dimensions of food security such as availability, stability, safety and access to food around the world. Using GIS, Matuschke (2009) constructed a food density map of the world to identify the future food security hotspots. In a similar way, Huang et al., (2009) used remote sensing, GIS techniques to identify the landuse change in the peri-urban zones of Taipei, and showed how urbanisation is causing landuse change. They also worked out the impact of the landuse changes on the global environmental change. In the paper titled 'Urbanisation and Its Impact on Agricultural Lands in Growing Cities in Developing Countries: A Case Study of Tamale in Ghana', Naab et al., (2013) highlights not only the landuse planning response to urbanisation but also explains its influence on food (in)security within the context of urbanisation. It also provides vivid information 
on how different policies can be taken to meet the crisis of food security. The findings of this research bear similarity to the "losses of agricultural land due to infrastructural development on Rajshahi District of Bangladesh" (Islam and Hassn, 2013). Using Remote Sensing and GIS techniques, Islam and Hassn (2013) found out the losses of agricultural land due to infrastructural development from 1977-2010. In doing so, they not only analysed change detection but also predicted on future availability of agricultural land. David Satterthwaite, Gordon McGranahan and Cecilia Tacoli (2010) seemingly discussed the impact of urbanisation on food production and on climate change. Here, they studied the relations between urban change, food demand and rural urban linkages and introduced the concept of urban agriculture. Urban agriculture or urban farming is an act of cultivating, processing, and distributing food in or around a village, town, or city. Food security, nutrition, and income generation are key motivations for urban agriculture. Earlier in 2002, Acharya et al., studied the impact of urbanisation on sustainable agriculture in Malaysia where they discussed about the changes in economic structure of Malaysia due to urbanisation and its impact on natural resources - urban waste generation, air pollution, water pollution, land conversion and species extinction.

Notwithstanding, food security was previously linked with climate change, nutrition, poverty and several other issues, while infrastructural development was mainly linked to economic development and environment. A real paucity of work is observed regarding the relation of urbanisation, infrastructural development and food security especially in a developing country like India where rapid, haphazard, unplanned urbanisation are causing great loss to farmland. Hence, this study is an attempt to examine the pace at which urbanisation; infrastructural development is consequent upon rapid landuse change and its influence on food security in parts of Hugli district. The findings demonstrate that urbanisation in the study area is consequent upon rapid landuse change, decrease in the land under cultivation, lower yield rate of crops, affecting on the future food security as well as perceptible pressure on the ecological balance of the region as a whole. Objectives of the research and methodology are discussed in the following section.

\section{Objectives and Methodology}

The key objectives of the present study are:

- to assess the rate of urbanisation in the selected parts of Hugli district,

- to examine the extent to which rural landuse is affected by urban extension and infrastructural development,

- to probe into the rate of decrease of agricultural land and productivity and

- to estimate the future food security of the study area

The research is based on both primary and secondary data. In order to understand the role played by the Public Distribution System (PDS) in food security, the primary data has been collected using random sampling method. For this, 200-structured questionnaire survey was conducted amongst the local residents of the study area to identify the extent to which the locals are availing the PDS or in actuality, how much food is available to the people. Secondary data has been obtained from District Statistical Handbook, District Census Handbook of Hugli district from the year 1951-2011 to identify the rate of urbanisation. The increasing per cent of urban population, the rise of the number of Census Towns are calculated between the periods of 1951-2011. Block Wise Landuse Data of Agricultural Department of West Bengal from the year 2000-2013 is followed to encounter the change of net sown area and non-agricultural landuse with increasing urban population. Regression analysis and Spearman's ranking Correlation Coefficient are calculated to understand the correlation among net sown area, urban expansion, and urban population. Hugli District Gazetteer is followed for understanding the changing nature of urbanisation and status of agriculture of the study area. Satellite imagery of the study area LANDSAT 5 TM, November 1996 and LANDSAT $8 \mathrm{OLI}$ (30-metre spatial resolution), November 2016 has been used to extract information 
regarding the change of landuse pattern. Supervised classifications of both the images are conducted to identify the nature and the extent of landuse change. In addition, the research used several techniques like Markov Chain analysis for future landuse change prediction, population projection and projection of future yield rate aimed at understanding the future predicament regarding food security. Maps are prepared using ArcGIS 10.3.1 and Erdas Imagine 9.2 software. In the light of these methods, this research explored the following questions:

- To what extent urban extension and infrastructural development are affecting rural landuse in the study area.

- How the decreased agricultural land and productivity affects future food security?

In order to probe these questions, the research considered some selected blocks of the productive agricultural area of Hugli district as areas under review to probe into urbanisation effective in altering the rural landuse with possible threat to future food security. The urbanized blocks of Hugli district are SerampurUttarpara, Chanditala I \& II, Jangipara,
Balagarh, Panduah, Chinsurah Magra, Singur and Haripal. Amongst these, the SerampurUttarpara block is highly urbanised. Here, the urban population is $76.10 \%$ and the urban area is $53 \%$ and the net sown area is only 653 hectare during 2011. The block also bears a long history of urbanisation dating back to 1951(Serampore was class II town and Uttarpara was class IV town according to 1951 Census). Thus, the block is not considered as productive agricultural area. Except for the Serampur-Uttarpara block, all the other blocks have greater extent of net sown area and all of them are experiencing rapid urbanisation and decrease of cultivated area. All these blocks have recent history of rapid urbanisation and abrupt change of landuse. For examplesJangipara, Chanditala I had no urban extension in 2001 whereas Chandiatala II, Balagarh, Pandua, Chinsurah-Magra and Haripal experienced greater degree of urbanisation from 2001 to 2011(Table 1). Thus, they have been considered for the current study. The CD (Community Development) blocks selected under Hugli district are Chanditala I \& II, Jangipara, Balagarh, Panduah, Chinsurah Magra, Singur and Haripal (Figure 1).

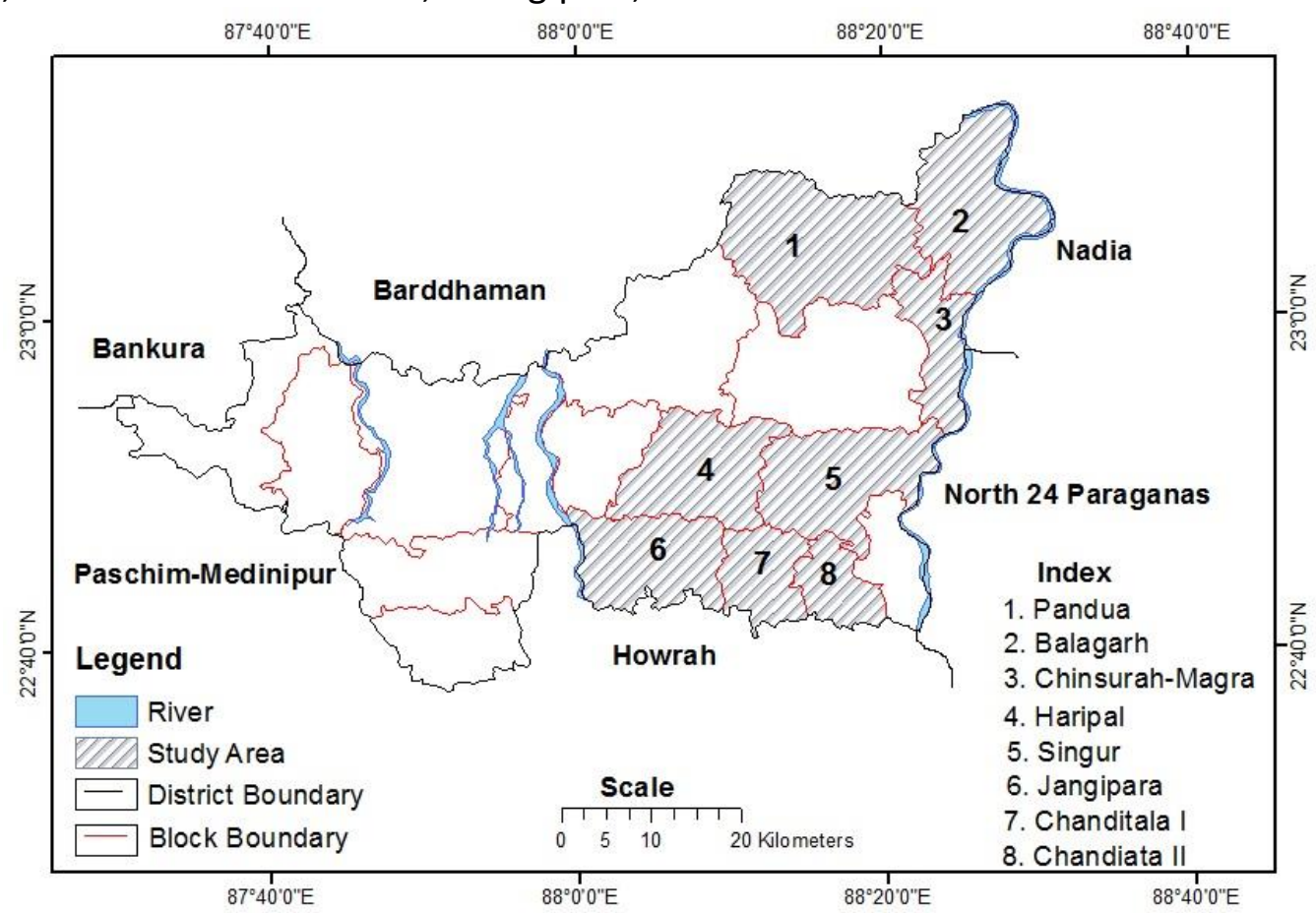

Figure 1: The Study Area Source: Prepared by the Authors 
Table 1: Urbanisation and Agricultural Statistics Block

Percentage of Urban Population to Total Population

$\begin{array}{cc}\text { Urban Area } & \text { Total Number } \\ \text { in } \mathrm{km}^{2} & \text { of } \mathrm{CT}\end{array}$
of CT
Non-

Agricultural

Landuse in

hectares

\begin{tabular}{|c|c|c|c|c|c|c|c|c|c|c|}
\hline & 2001 & 2011 & 2001 & 2011 & 2001 & 2011 & $2000-01$ & $2010-11$ & $2000-01$ & 2010-11 \\
\hline Balagarh & 2.2 & 12.31 & 1 & 9.54 & 1 & 4 & 3989 & 5541 & 15605 & 14994 \\
\hline Pandua & 9.56 & 15.52 & 3.8 & 8.55 & 1 & 4 & 4846 & 6051 & 22896 & 22325 \\
\hline Haripal & 0 & 1.75 & 0 & 1.24 & 0 & 1 & 3526 & 4324 & 14557 & 13715 \\
\hline Singur & 7.49 & 18.98 & 6.4 & 20.21 & 1 & 6 & 6348 & 10133 & 12373 & 8920 \\
\hline $\begin{array}{c}\text { Chinsurah } \\
\text { Magra }\end{array}$ & 46.83 & 64.87 & 19.9 & 24.43 & 9 & 15 & 4113 & 6644 & 4996 & 2861 \\
\hline Jangipara & 0 & 7.44 & 0 & 5.86 & 0 & 1 & 3620 & 4173 & 12762 & 12166 \\
\hline Chanditala I & 0 & 41.79 & 0 & 30.83 & 0 & 9 & 1598 & 1958 & 7578 & 7336 \\
\hline Chanditala II & 42.36 & 69.13 & 18.3 & 30.3 & 10 & 15 & 2263 & 4552 & 4552 & 2457 \\
\hline
\end{tabular}

Data Source: District Statistical Handbook, 2000-01, 2010-11 \& Department of Agriculture, West Bengal (Computed by the Authors)

\section{Urbanisation and its Effect on Agriculture}

Urbanisation leads to broad-based rural to urban transformation relating population, landuse, economic activity, culture, or indeed any one of these (McGranahan et al., 2014:6). It involves an increase in the size of urban populace, growth in the number and size of urban places with increasing concentration of population in such places (Hauser et al., 1954; Padam et al., 2001:2-4 and Mukherjee et al., 2017). Over recent decades, developing countries show trends of decrease in rural landuse and an increase in urban landuse through urbanisation (Mundia et al., 2006; Jat et al., 2008; Dewan et al., 2009 and Yin et al., 2011). Rapid urbanisation is related with the disappearance of rural agricultural land, spatial discontinuity and sustainability challenges (Yeh et al., 1999; Xie et al., 2006 and Wei, 2007). Agricultural land is more or less level to slanting, well drained and cleared, not prone to erosion and as of now connected to existing transportation infrastructure. These features make it the lowest cost; therefore, agricultural land loss is substitute to newly urbanised land (Mothorpe et al., 2013: 2). Urbanisation plays major role in the territorial ecological change and, therefore, the increasing rate of urbanisation, the expansion of urban lands and landuse and land cover change have become important issue in the study of dynamics of landuse change (Sanchez-Rodriguez et al.,
2005, Dong et al., 2007). The study area of Hugli district had only 22 Census Towns (CT) in 2001. The number of CTs increased to 56 in 2011. Jangipara, Haripal and Chanditala I Block had no urban area or CT in 2001, but they have pocketed 10 new CTs in 2011 (Figure 2).

Table 1 shows urbanisation and agricultural statistics. Census has defined Census Towns (CTs) as places that fulfil three overlay criteria of populace of 5000, 75 percent of male main working population occupied in nonagricultural pursuits and density of 400 persons per sq. $\mathrm{km}$. They can be effectively characterised as transitional urban areas at various levels of transition, which is also known as urbanisation by implosion, where massive density of population, economic change and access to good level of public services prompts to urban development. They are not governed by urban local governments (Ghosh, 2014: 29; Chakraborty, 2015: 170 and Karmakar, 2015: 22). There is exponential rise of urban population and the number of CTs in all the blocks of the study area. Haripal, Jangipara and Chanditala I had little experience of growth in urban population up to 2001, but in 2011, urban population increased to a considerable height, which in turn signals the pace of urbanisation in the study area as explained below:

Balagarh block included two Non-Municipal (NM) towns such as Mirdhanga and Sripur since 
1991. Before 1991, the block was very rural in character. Badhagachhi gained the status of CT in 2001 and Mirdhanga, Jirat, Sripur of this block gained the same status in 2011. From 1991-2011, 4.72\% area was urbanised in Balagarh block. Similarly, Chanditala I was rural in character with rural landuse pattern before 2011 , but $32.98 \%$ of its total area was declared urbanised due to development of nine new CTs in 2011. They are Masat, Jangalpara, Gangadharpur, Dudhkalmi, Nababpur, Kumirmora, Ramanathpur, Bhagabatipur and Manirampur. Chanditala II block had four NM towns such as Barijhati, Kharsarai, Purba Tajpur and Begumpur in 1991. During 2001, these NM towns transformed into CTs, and further there was emergence of six new CTs such as Chikrand, Pairagachha, Monohorpur, Garalgachha, Krishnapur and Mrigola. Monoharpur and Mrigola CTs of the block lost their status and again returned to their rural landuse during 2011 because of insufficient infrastructural development. Again, there was development of new CTs in the block namely Tisa, Kapashanria, Jaykrishnapur, Baksa, Panchghara, Janai and Naiti during the same period. Thus, $57.69 \%$ of its area was urbanised with the development of 15 CTs from 1991 to 2011. Chinsurah and Magra blocks had three NM towns (Raghunathpur, Madhusudanpur, Bandel Thermal Power Project Town) and four OGs (Out Growth - Sankhanagar, Barakhejuria, Chak Bansberia, Kamarpara) in 1981. During 1991, Sankhanagar and Chak Bansberia transformed from OG to NM. During 2001, eight CTs emerged in the block such as Kodalia, Raghunathpur, Madhusudanpur, Amodghata, Sankhanagar, Kulihanda, Simla and Dharampur. In 2011, further seven CTs were added in the Block namely Kola, Hansghara, Alikhoja, Chak Bansberia, Manushpour, Keota and Naldanga. From 2001 to 2011 the total number of CTs increased from nine to 15 , thus $30.49 \%$ area was urbanised in Chinsurah Magra block. Haripal block had one NM town (Haripal NM) in 1971, but it lost its urban status in 1981. Since then Haripal maintained its rural landuse pattern until 2001. During 2011, one new CT, Bargachhia, was found to be developed within the Haripal block with urbanisation of 0.67 per cent of its total area. Pandua was also a NM town under Pandua block since 1961; it gained the status of CT in 2001. In 2011, $3.09 \%$ area was declared urbanised in Pandua due to emergence of three new CTs (Batika, Purusottampur and Namajgram) along with Pandua CT. Singur NM existed in Singur block since 1961. An urban OG (Kamarkundu) was found in this Block since 1991. Singur NM was declared CT in 2001, and within 2001-2011 the share of urbanisation further increased to about $8.88 \%$ with the emergence of five new CTs (Balarambati, Nasibpur, Jagatnagar, Baruipara, Barai) along with singur CT. Jangipara block retained its rural landuse pattern till 2001, but with the development of Rajabalhat CT in 2011, the Block gained 3.57\% of its area under urban category in 2011 (Figure 2 ). From the current analysis it is clear that greatest extent of urbanisation in the study area took place from 2001 to 2011 (Table 1). The eastern part of the study area is mostly covered by six municipalities (M). That is why there is no agricultural landuse in that portion. The municipalities are Bansberia, Hooghly Chinsurah, Chandannagor Municipal Corporation, Bhadreshwar and Champdani. Their area increased from 50.78 sq. km in 1991 to 63.28 sq. $\mathrm{km}$ in 2011.

The trend line in Figure 3 displays fall in net sown area with urbanisation in all the blocks of the study area. Balagarh, Pandua, Haripal, Singur, Chinsurah-Magra and Chanditala II block shows greater fall of net sown area and the rest of the blocks project comparatively lesser decrease of net sown area due to urbanisation (Figure 3). The area under non-agricultural use is found to increase from 2001 to 2011 in all the blocks of the area under review. The blocks Balagarh, Pandua, Singur, Chinsurah-Magra, Chanditala II shows greater degree of increase of area under non-agricultural landuse than the other blocks of the study area (Figure 4). The above facts prove that the district has experienced a reciprocal loss of net sown area due to substantial gain in the rates of urbanisation. There is also increased use of land into non-agricultural uses such as settlement, 
building construction, industry, roads, be used as a method to compute the extent of infrastructure, etc. Urbanisation is vital to loss urbanisation as a responsible factor in of territory under agriculture. In other words, transforming rural landuse pattern. The result urbanisation has always been stretched out on shows that there is a strong inverse relationship agricultural belt (Satterthwaite et al., 2010). between the growth of urban area and the net Spearman's ranking correlation coefficient can sown area (Table 2).

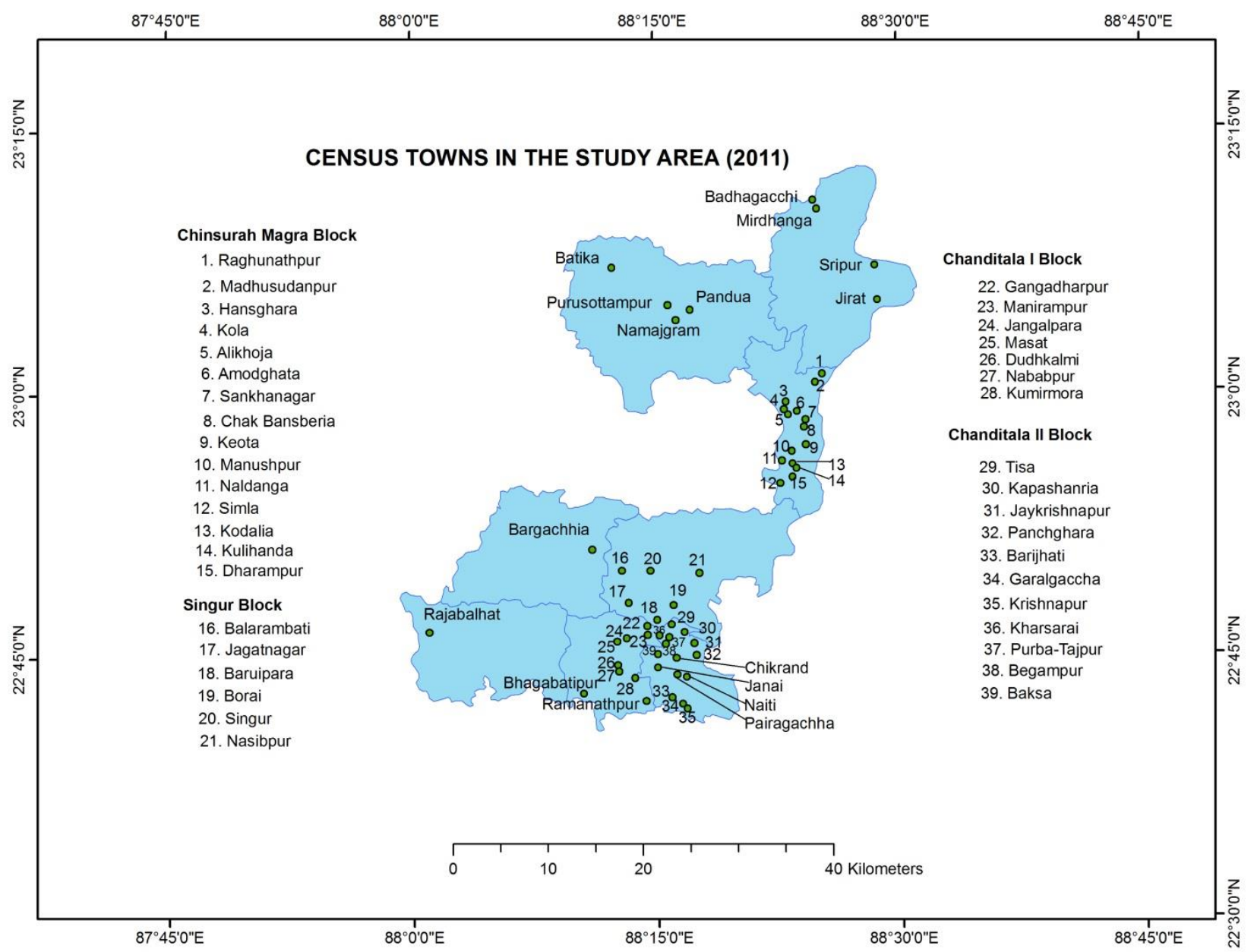

Figure 2

Data Source: District Census Handbook, 2011

Table 2: Calculation of Spearman's Ranking Correlation Coefficient Block Urban Area in Rank Net sown Area Rank Difference of $d^{2}$

Sq. $\mathrm{Km}$.

in Hectares

Rank (d)

\begin{tabular}{ccccccc}
\hline Haripal & 1.24 & 1 & 13715 & 6 & 5 & 25 \\
\hline Jangipara & 5.86 & 2 & 12166 & 5 & 8 & 5 \\
\hline Pandua & 8.55 & 3 & 22325 & 14994 & 7 & 3 \\
\hline Balagarh & 9.54 & 4 & 8920 & 4 & 1 & 9 \\
\hline Singur & 20.21 & 5 & 2861 & 2 & 4 & 1 \\
\hline Chinsurah Magra & 24.43 & 6 & 2457 & 1 & 3 & 3 \\
\hline Chanditala I & 30.03 & 7 & 7336 & 3 & 5
\end{tabular}

Data Source: District Statistical Handbook, 2011; Dept. of Agriculture, WB (2010-11) (Computed by the Authors) Spearman's Ranking Correlation Coefficient: $r=1-6 * \Sigma d^{2} / n^{3}-n$ $=-\mathbf{0 . 7 3}$ 


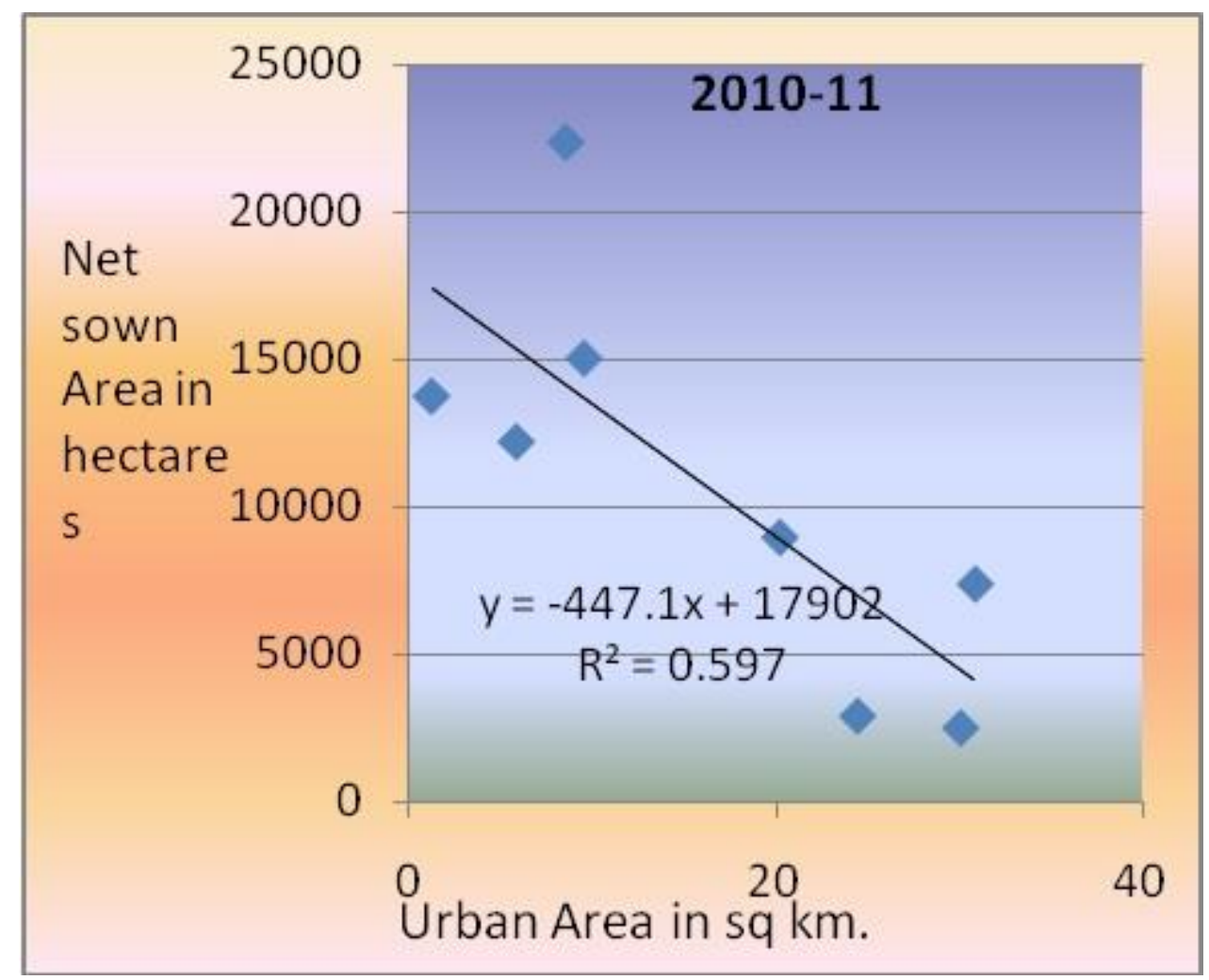

Figure 3: Regression Analysis

\section{Increasing Trend Of Non-agricultural Landuse}

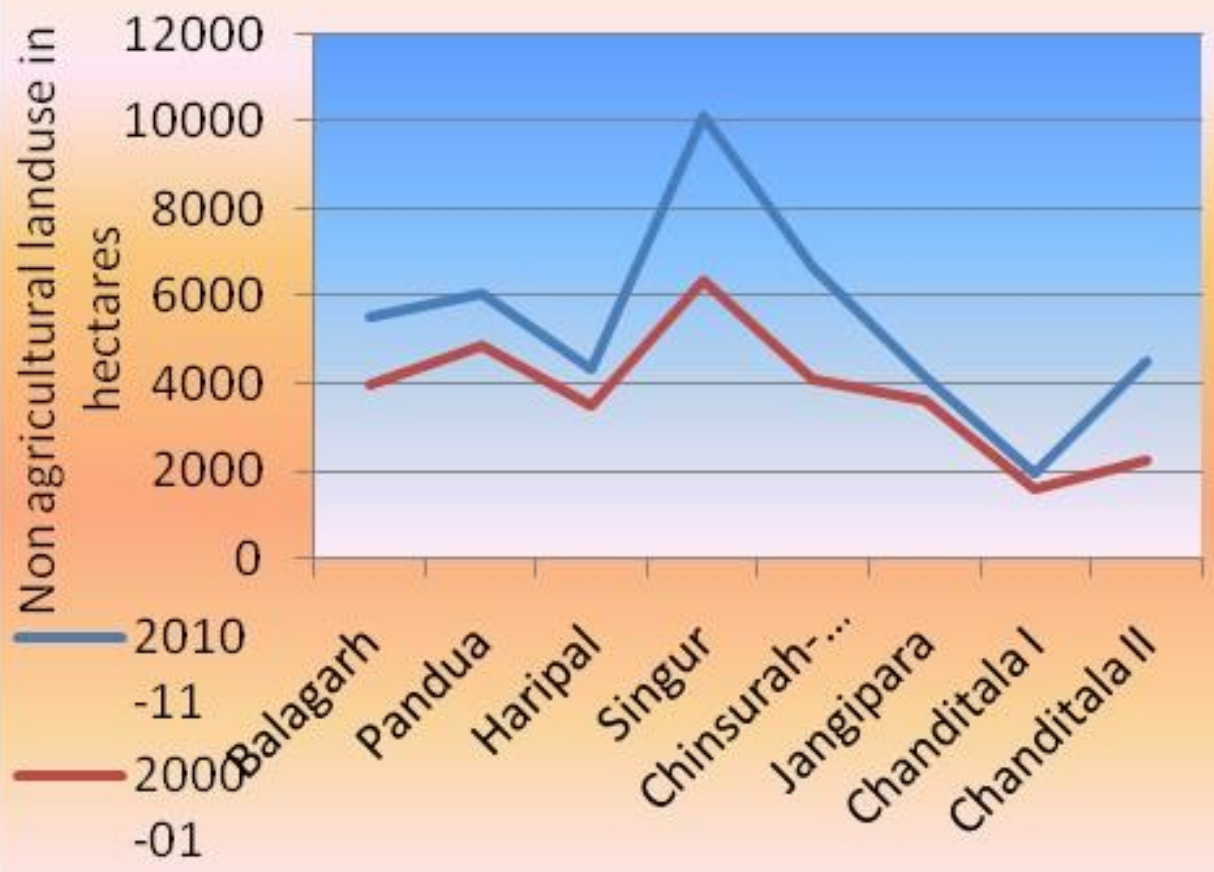

Figure 4

Data Source for Figures 3 and 4 : District Statistical Handbook, Department of Agriculture, West Bengal (2000-01 \& 2010-11)

Infrastructural Development in the Study Area the quality of life by providing better transport Infrastructural development is essential for maintaining economic growth and improving and communication system (Shilling, 2007: 5). Urbanisation indicates economic growth and creates immense demand for private and public 
sector infrastructure advancement (Aldred, 2012). According to Berdi and Cavinato (1982), transport and communication are the most important variables for infrastructural development (Nayak, 1999: 60). The study area has experienced rapid infrastructural development. The lengths of both surfaced and unsurfaced road maintained by Public Works Department (PWD) and Zilla Parishad have been varied during 2000-01 to 2011-12. Here, in most of the blocks the surfaced and unsurfaced roads under PWD and Zilla Parishad are mostly built into roads maintained by Gram Panchayat, Panchayat Samiti and The Pradhan Mantri Gram Sadak Yojana (PMGSY) (Figure 5). Thus, the total length of road has increased in most of the blocks from 2000-01 to 2011-12 (Figure 6). The data regarding the length of the roads maintained by PMGSY is not available for Chinsurah Magra and Singur block. Thus, only in these two blocks changes in length of road cannot be projected in the diagram. PMGSY was launched on $25^{\text {th }}$ December 2000 by Government of India to provide rural road connectivity to detached rural habitation. The works are executed by State Governments and monitored by the Ministry of Rural Development through the National Rural Roads development Agency (NRRDA) set up for this purpose. $^{1}$

\section{Remote Sensing Technologies, Detection of Landuse Change and Prediction of Future Change of Landuse Using Markov Chain Model}

Advancement of Remote Sensing technologies facilitates us in detection of landuse/land cover change over a period of time (Seto et al., 2003; Weber et al., 2003 and Pellika et al., 2004). They are available and accessible at high temporal resolution and the cost is lower than the other traditional methods of landuse change detection (Jensen, 1983; Martin et al., 1989 and El-Raey et al., 1995). In the current research, present landuse change and future probability of further landuse change has been worked out to understand the degree to which cropland can be affected by urbanisation and infrastructural development. Satellite imagesLandsat 5 TM, November 1996 and Landsat 8 OLI, November $2016 \quad$ (30 metre spatial resolution) have been analysed to detect the landuse change in the area under review. Supervised classification has been done to extract the required information. The result is then matched with Google Earth image of the study area. A post-classification matrix is worked out through change detection to analyse the nature, rate, and location of landuse change (Table 3). Markov Chain Model has been applied to show the probability of changes from each class of landuse to each different class in future. Markov Chain Model, in a general sense is a projection model, which demonstrates the probabilistic movements of an individual in a system consisting of discrete states. Markov Chain recognises both time and a finite set of states as discrete values to forecast the future landuse change. Transitions between the states of the system are traced in the form of a transition matrix that accounts the probability of moving from one state to the next (Clark, 1965; Hegazy et al., 2015). Application of Markov Chain to model change in landuse started since the year 1970 at a variety of spatial scales as a substitute to the use of large-scale urban simulation models for forecasting landuse alteration (Bell et al., 1977; Baker, 1989 and Kiran, 2013). Table 4 presents the Probability Transition Matrix of different landuse types of the study area. In this research, 1996 and 2016 landuse maps are prepared to predict the future landuse change during 2056 in the area under review (Table 5).The result shows that there is a rapid conversion of agricultural land/cropland into settlement and other constructions from 1996 to 2016. In many cases, area under bare land, plantation, and water bodies have been converted to built up area. The cropland has decreased from 99612.43 hectares to 82693.4 hectares and the built up area simultaneously increased from 21026.2 hectares to 41967.7 hectares during 1996-2016 (Figures 7 and 8).

\footnotetext{
${ }^{1}$ Pradhan Mantri Gram Sadak Yojana (PMGSY), retrieved from, http://pmgsy.nic.in (accessed September 10 2017)
} 


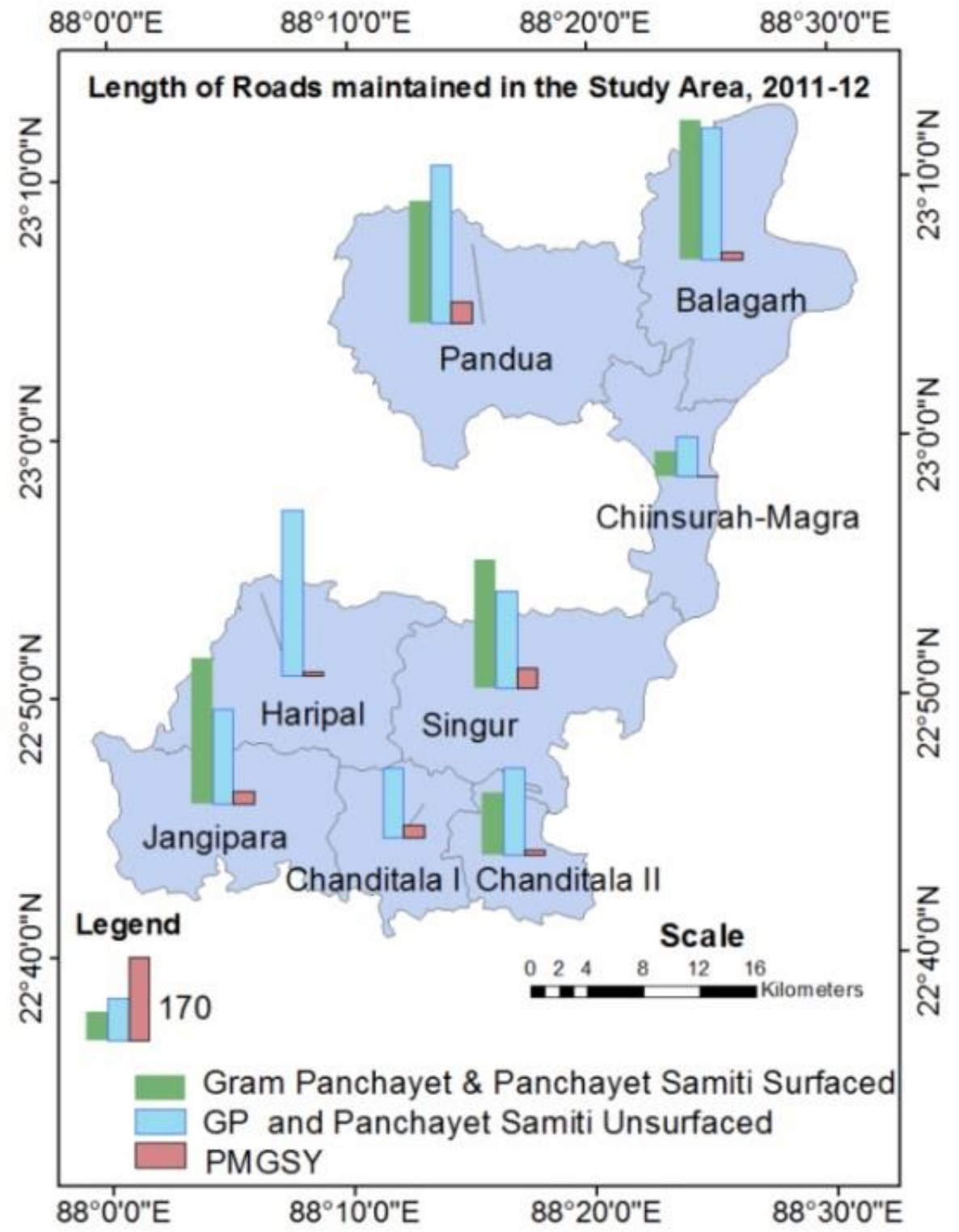

Figure 5: Data Source: Ex-Engg., P.W.D. Roads, Ex-Engg., Zilla Parishad, 2000-01, 2011-12

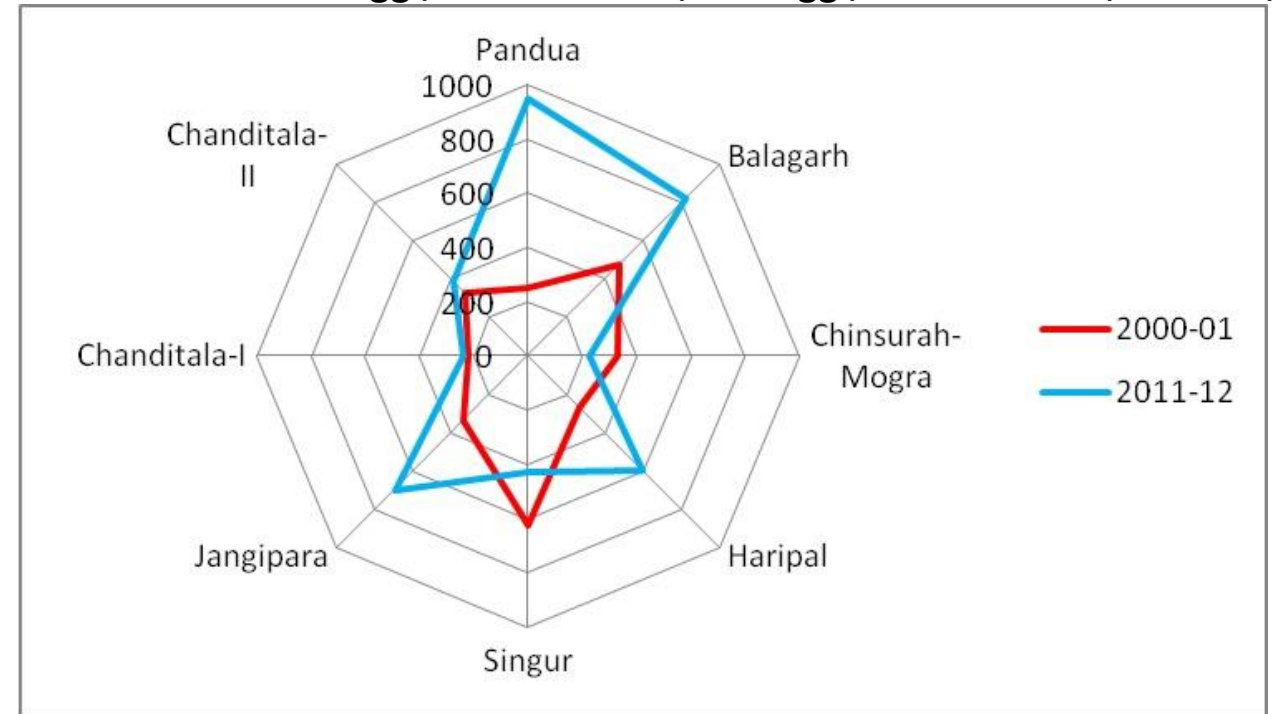

Figure 6: Blockwise Increase of Length of Road

Data Source: District Statistical Handbook, 2011-12 
All the blocks of the study area shows decrease in agricultural land and increase in area under built up. Pandua, Balagarh, Chinsurah-Magra, Haripal, Singur and Chanditala II blocks show more or less similar rate of decrease of area under cropland and increase of built up area. Jangiapara and Chanditala I block also display same character but the rate of increase of built up area is more than the rate of decrease of cropland (Figure-9). The Markov Model further predicts that the cropland will decrease from $62.77 \%$ to $42.90 \%$ and the built up area will increase from $31.86 \%$ to $54.63 \%$ of the total area from 2016 to 2056. Future projection of landuse again signifies that in future the change of landuse will have detrimental effect on cropland (Table 5).

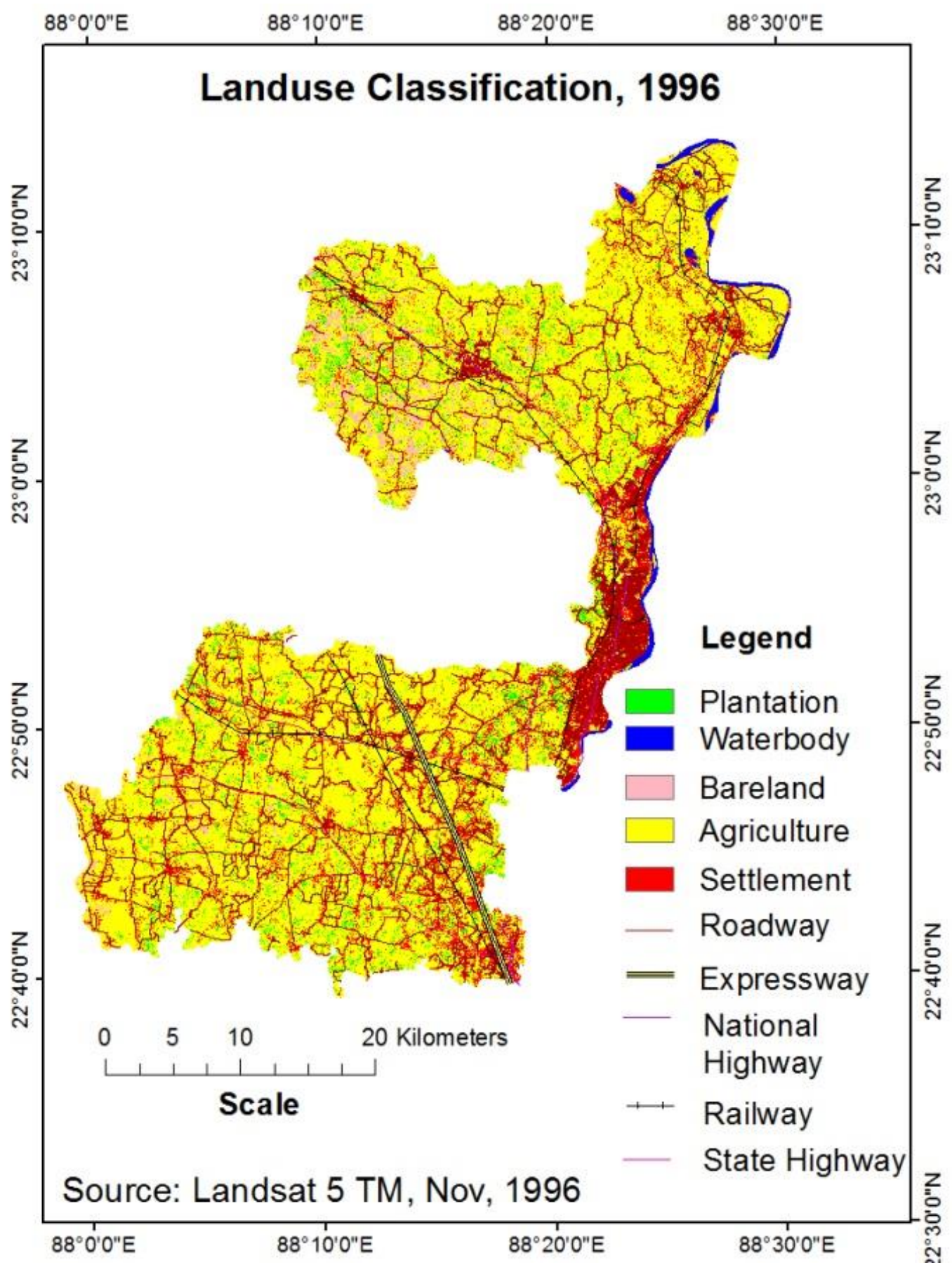

Figure 7 


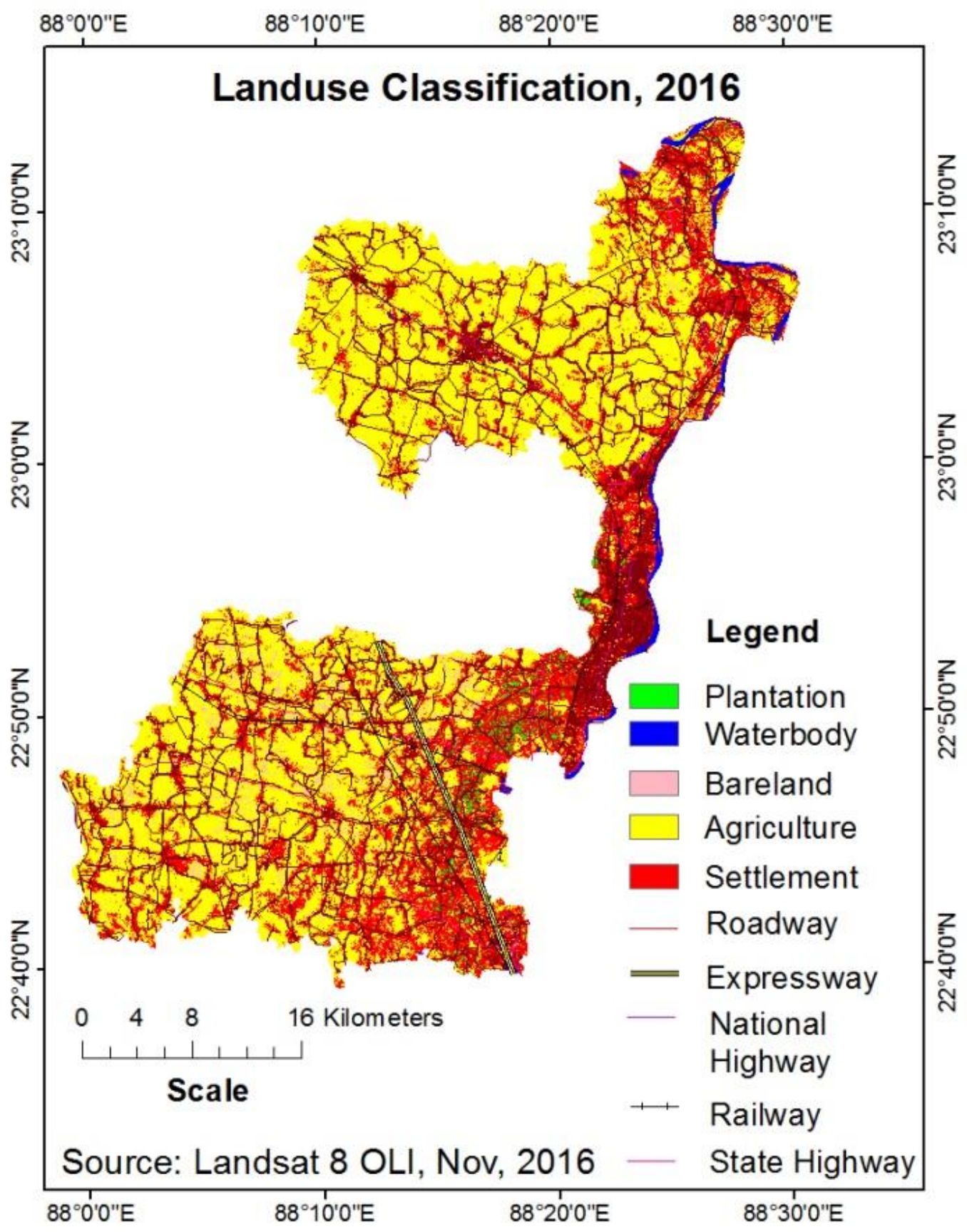

Figure 8

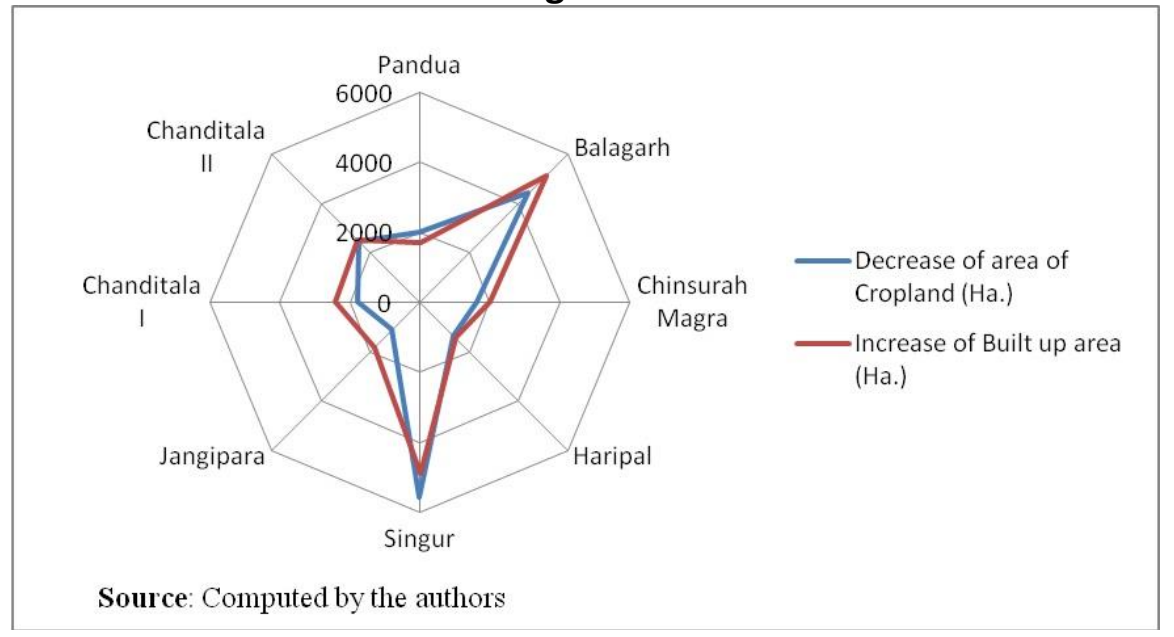

Figure 9: Blockwise Decrease of Area under Cropland and Increase of Built Up Area 
Table 3: Post Classification Matrix from 1996-2016 1996 Plantation Bare land Wate body

\begin{tabular}{llrrrrrr}
\hline 2016 & Plantation & 1779.39 & 0 & 0 & 0 & 0 & 1779.39 \\
\hline Bare land & 0 & 3086.01 & 0 & 0 & 0 & 3086.01 \\
\hline Water body & 0 & 0 & 2219.4 & 0 & 0 & 2219.4 \\
\hline Crop Land & 200.5 & 748.93 & 0 & 81743.97 & 0 & 82693.4 \\
\hline Built Up Area & 1663.47 & 1000 & 409.6 & 17868.43 & 21026.2 & 41967.7 \\
\hline Total & 3643.36 & 4834.94 & 2629 & 99612.43 & 21026.2 & 131745.9
\end{tabular}

Source: Computed by the Authors

\section{Table 4: Transition Probability Matrix Derived from Landuse Map, 1996-2016}

\begin{tabular}{lrrrrrr} 
& Plantation & \multicolumn{1}{c}{ Bare land } & Water body & Crop Land & Built Up Area & Total \\
\hline Plantation & 0.488392583 & 0 & 0 & 0.0550316 & 0.456576 & 1 \\
\hline Bare land & 0 & 0.638272657 & 0 & 0.154899544 & 0.206827799 & 1 \\
\hline Water body & 0 & 0 & 0.844199315 & 0 & 0.155800685 & 1 \\
\hline Crop Land & 0 & 0 & 0 & 0.820620178 & 0.179379521 & 1 \\
\hline Built Up Area & 0 & 0 & 0 & 0 & 1 & 1
\end{tabular}

Source: Computed by the Authors

Table 5: Future Projection of Landuse Change by Applying Markov Chain Model

\begin{tabular}{lcccc} 
Landuse Classes & \multicolumn{2}{c}{2016} & \multicolumn{2}{c}{2056} \\
\cline { 2 - 5 } & Hectares & Percentage & Hectares & Percentage \\
\hline Plantation & 1779.39 & 1.35 & 424.43 & 0.322157886 \\
\hline Bare land & 3086.01 & 2.34 & 1257.22 & 0.954275941 \\
\hline Water body & 2219.4 & 1.68 & 1581.71 & 1.200575714 \\
\hline Crop Land & 82693.4 & 62.77 & 56512.8 & 42.89528119 \\
\hline Built Up Area & 41967.7 & 31.86 & 71969.8 & 54.62770927 \\
\hline Total & 131745.9 & 100 & 131745.96 & 100
\end{tabular}

Source: Computed by the Authors

Impact on Food Security

Rapid economic growth combined with increasing population, reduction in agricultural land and decreasing soil availability for agricultural production are correlated with food security in developing countries like India and China (Yang et al., 2000; Lin et al., 2003; Zhang et al., 2004 and Chakraborty et al., 2016). Scientists and agriculturalists have already predicted decrease in crop yields, as there is no such scope for further expansion in the agricultural land (Sajjad et al., 2012 and Sayeed, 2014: 5). Greater urban landuse in fertile land has negative impact on soil resources, and on food security. The effect is decline in agricultural productivity, low standard of living, and threat to future food insecurity (Blum, 1997; Belal et al., 2011 and Naab, 2013: 257).

Today our existing knowledge fails to ascertain direct cause-effect relationships between urbanisation and its influence on degradation of soils. Urbanisation has definite adverse impact on soil as it alters the biological, chemical and physical properties of soil and thereby, debase its quality in such a manner (soil pollution by industrial and municipal sewage and polluted surface water through irrigation and flooding events) that it leads to loss of vegetation, poor water infiltration, accumulation of heavy metal, excess water 
runoff and soil erosion (Chen, 2007: 8; use of inorganic fertilisers, pesticides and other Marcotullio, 2008 and Kharel, 2011). Again, sorts of agro-chemicals are detrimental to soil urbanisation and population growth creates fertility and they are often responsible for soil huge pressure on the existing agricultural degradation (Bhattacharyya et al., 2015:3535, production. In order to feed growing numbers Massah, 2016: 44). The use of these fertilisers of people, there is greater use of fertilisers, may provide higher yield at present but it might pesticides, and insecticides in the field. The use have a negative effect to natural ecosystem in of NPK in soil has an increasing trend in Hugli the long-term.

district as a whole (Figure 10). Indiscriminate

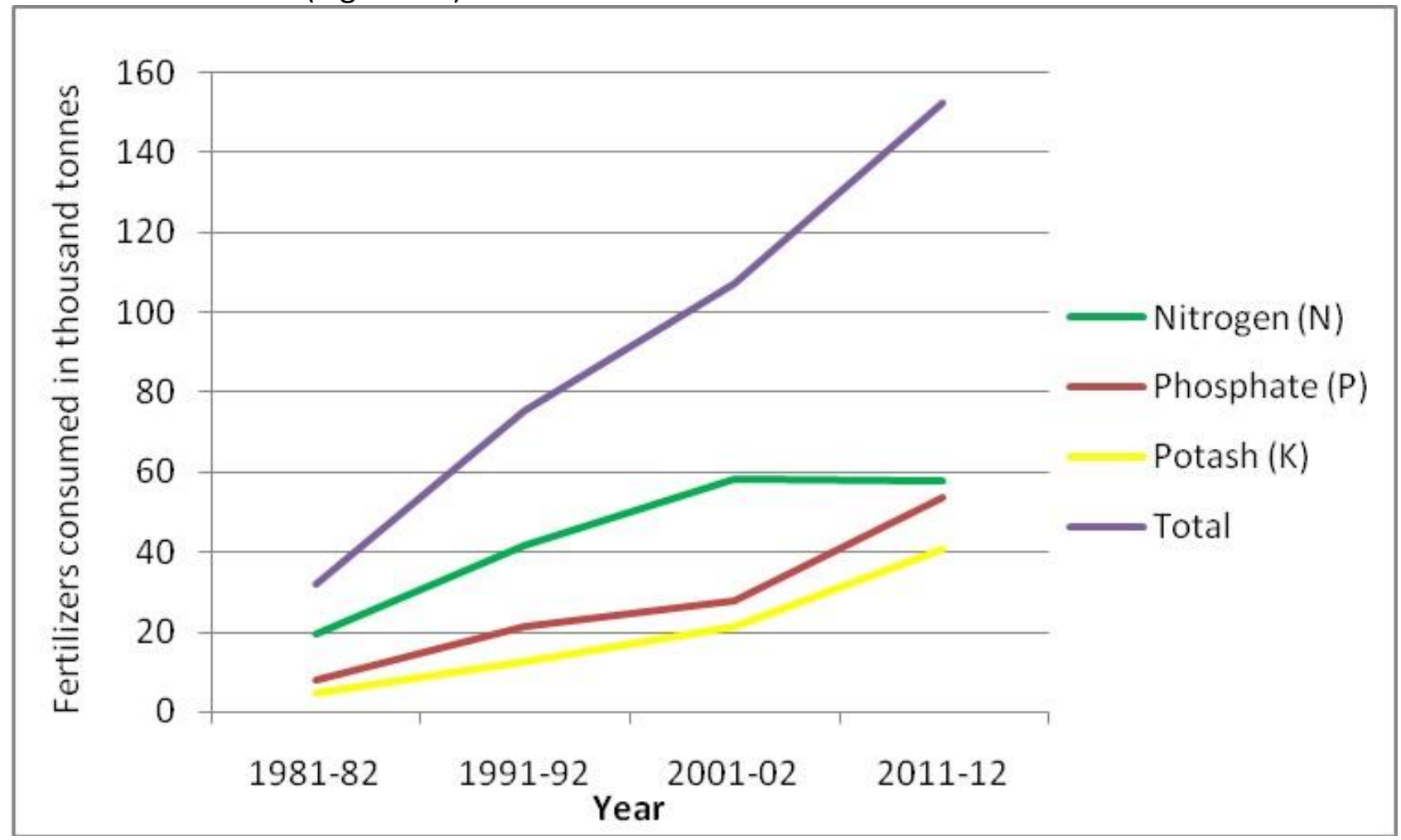

Figure 10: Use of NPK in Soil

Source: Directorate of Agriculture, West Bengal, 1981-82 to 2011-12

Loss of productive land is the principal cause of inviting threat to food security in the study area. Loss of agricultural land is directly consequent upon reduction in production of principal and non-principal crops. Urbanisation and infrastructural development in the area have affected all four dimensions of food security as explained below:

\section{Food Availability}

Food production and supply are the two most important components of food availability.

\section{Population Projection and Projected Yield Rate}

Quetelet, a French Mathematician propounded Population Projection in 1835. It helps us to calculate the growth of population based on the present and past conditions. The planners and administrators to gauge economic and social development often use this but this method not only measures population. Here, in this paper geometric method of projection is utilised to understand both the population and yield rate of the study area in near future. The projected population and production is based on present socio-economic and cultural situation. $^{2}$

\footnotetext{
2 Population Projections: Meaning, Types and Importance, retrieved from,

http://www.sociologydiscussion.com/demography/popul ation-projections/population-projections-meaning-typesand-importance/3058 (accessed September 18 2017)
} 
Projected Population or yield rate $=$ Population of current year or Yield rate of the current year $(1+r / 100)^{n}$

$r=$ average annual growth rate of population/ average annual yield rate $\mathrm{n}=$ number of year involved in the period of time

Following the above formula, Projected Population and Yield rate have been calculated for the area under review.

Table 6 shows that the projected yield rate of some major crops has decreased from 2000-01 to 2051-52. Aman, Boro and Potato are some of the major crops of Hugli district. The yield rates of these crops have been taken into consideration. Yield rate of Aman and Boro have decreased in the study area but yield rate of Potato is found to increase in Pandua, Chinsurah-Magra, Singur, Jangipara, Chanditala II. The increasing yield rate of Potato in some of the blocks is a positive sign for the district as a whole but decreasing yield rate of Aman and Boro as staple foodgrains are a negative impact. This fact raises a fundamental question, whether the district or the state will rely on greater production of potato, precisely because the decreasing yield rate of rice cannot be compensated by greater yield of potato, as rice is the main source of nutrition for the poor.

\section{Table 6: Projected Yield Rate of Some Major Crops}

\begin{tabular}{|c|c|c|c|c|c|c|c|c|c|}
\hline \multirow[t]{2}{*}{ Block } & \multicolumn{3}{|c|}{ Aman } & \multicolumn{3}{|c|}{ Boro } & \multicolumn{3}{|c|}{ Potato } \\
\hline & $\begin{array}{l}-1 \\
\text { o } \\
\text { ઠ̊ } \\
\text { ㅇ }\end{array}$ & $\begin{array}{l}\stackrel{\sim}{7} \\
\stackrel{-}{-} \\
\stackrel{-}{\circ}\end{array}$ & 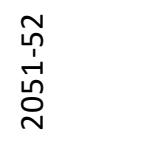 & $\begin{array}{l}-1 \\
\text { ’ } \\
\text { ઠ̊ } \\
\text { ઠ }\end{array}$ & $\begin{array}{l}\stackrel{\sim}{7} \\
\underset{1}{+} \\
\stackrel{-}{-} \\
\stackrel{\sim}{N}\end{array}$ & 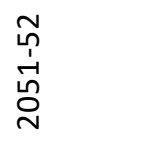 & $\begin{array}{l}\text { ㅇ } \\
\text { ᄋ́ } \\
\text { ᄋ } \\
\text { ㄱ }\end{array}$ & $\begin{array}{l}\stackrel{\sim}{-} \\
\stackrel{1}{+} \\
\stackrel{-}{\circ} \\
\stackrel{\sim}{N}\end{array}$ & $\begin{array}{l}\text { กิ } \\
\text { ஸे } \\
\text { ஸे } \\
\text { ○े }\end{array}$ \\
\hline Pandua & 3268 & 2920 & 1861 & 4232 & 2963 & 711.99 & 27986 & 29971 & 39422.38 \\
\hline Balagarh & 3218 & 2418 & 770.79 & 4342 & 2978 & 658.97 & 25645 & 23275 & 15792.02 \\
\hline Chanditala I & 3551 & 2336 & 437.48 & 4480 & 2739 & 382.69 & 28598 & 26490 & 19501.46 \\
\hline Chanditala II & 3579 & 2312 & 402.62 & 4619 & 2785 & 368.07 & 26975 & 28736 & 37007.16 \\
\hline Chinsurah Magra & 3447 & 2640 & 908.35 & 4854 & 1529 & 15.05 & 23062 & 29676 & 81365.25 \\
\hline Jangipara & 3689 & 2720 & 803.91 & 4296 & 3164 & 930.95 & 26842 & 27643 & 31093.27 \\
\hline Singur & 3187 & 2631 & 1222.01 & 4151 & 2888 & 676.67 & 31649 & 33057 & 39343.88 \\
\hline Haripal & 3284 & 2320 & 577.87 & 4374 & 3184 & 894.03 & 28540 & 24461 & 13199.43 \\
\hline
\end{tabular}

Table 7: Calculation of Population Projection

\begin{tabular}{cccc} 
Block & Population 2001 & Population 2011 & Projected Population of 2051 \\
\hline Haripal & 235,494 & 261073 & 394331 \\
\hline Jangipara & 201001 & 221578 & 327220 \\
\hline Pandua & 284231 & 316197 & 484287 \\
\hline Balagarh & 214784 & 228998 & 295904 \\
\hline Singur & 260827 & 276413 & 348643 \\
\hline Chinsurah-Magra & 211049 & 247055 & 463911 \\
\hline Chanditala I & 165837 & 179825 & 248613 \\
\hline Chanditala II & 213485 & 158396 & 156767
\end{tabular}

\section{Data Source: District Statistical Handbook, 2001, 2011 (Computed by the Authors)}

Table 7 presents the projected population of 2051 for the study area. It is found that only in Chanditala II, the total population has a decreasing trend, but in that particular block, urban population has increased largely as shown in Table 1. Due to the substantial decrease of rural population, total population has been reduced. The percentage of rural and urban population in the block is $57.64 \%$, $42.36 \%$ in 2001 and $30.87 \%, 69.13 \%$ 
respectively during 2011. Thus, the rural population decreased for about $26.77 \%$ while the increase of urban population is $26.77 \%$. The male (108893 in 2001, 79831 in 2011) and female population (104562 in 2001, 78565 in 2011) of the block has decreased from 20012011. It can be argued that migration to urban area is the main reason behind such decrease of rural population and increase of urban population. However, migration is not sexselective. The percentage of tertiary workers also increased from $57.05 \%$ to $79.13 \%$ from 1991 to 2011. In Chanditala II block, the number of CTs increased from 10 to 15 while Chanditala I block was completely rural in character in 2001 but emergence of nine new CTs in 2011 changed its character from rural to urban. Urbanised areas like Chanditala I block, Serampore-Uttarpara block and other Municipalities are just beside Chanditala II block. Rapid increase of urban population and number of CTs in Chanditala I and II block signify the fact that rural people have shifted within not only the urban areas of Chanditala II block, but also to the nearest CTs of Chanditala I Block and other urban areas near to the Block.

Food production does not increase at par with the increase in the population, which is evident from Tables 6 and 7. In future, agriculture will be a challenging pursuit to meet the demand of the increased population. The increased number of individual will require more food, which will have to be generated by greater agricultural production or by food imports (Matuschke, 2009: 5). If a prosperous agricultural region experiences decrease of cropland and yield rate of major crops and increase of population in near future, then it would pose an overall negative impact on the district and the state. This fact also signifies that the region may be dependent on food import in long run.

Here, one thing must be mentioned that importing food can be an option for countries like Japan where economic growth takes place in terms of industrialisation and the country is mostly reliant on food import from outside due to trade liberalisation (Tetsuji, 2009). In India the agricultural products imported from outside are cereals, pulses, milk, cashew nuts, fruits, sugar, oilseeds and vegetable oils. India's total expense for cereal and pulse import stands for 196.8 million dollars, which is $10.7 \%$ of the total agricultural import of the country in the period of $1999-2000 .^{3}$ Thus in case of developing countries like India, food import is not an option. If a region is dependent upon food import precisely due to decreasing food production then a crisis of food grain will generate high demand and low supply of food grains. Thus, food price will rise, the government subsidy in PDS will fall and the worst sufferer would be the poor section who falls below poverty line.

\section{Food Stability}

The increased food demand will press upon the transportation and distribution of food materials within the cities. This will put additional pressure on rural infrastructures, transport advancements, and food distribution outlets. Since these are already insufficient in urban areas of many developing countries, the stability of food supply may be jeopardised (FAO, 2008). In developing countries, urban poor are always at risk during extreme weather conditions and other climatic hazards ${ }^{4}$. Similarly, lower food availability in the study area will put threat to the access of food at all times especially during sudden scarcity of food due to natural hazards. When the availability of food will be less, the demand for food will rise and food prices would also rise. Thus, both rural and urban communities will be unable to sustain their livelihood and move to other places in search of work and food (Szabo, 2016: 32-33).

\footnotetext{
${ }^{3}$ Export and Import of Agricultural Products, retrieved from, http://www.indiabudget.nic.in/es 200001/chap820.pdf(accessed September 17 2017)

${ }^{4}$ World Disasters Report, 2010, https://www.ifrc.org/Global/Publications/disasters/WDR /WDR2010-full.pdf (accessed September 17 2017)
} 
Food Safety, Access of Food and role of Public Distribution System (PDS)

Access to food in urban areas are greatly dependent upon the relations between income and food prices (Atkinson, 1995: 154). Urbanisation indicates greater reliance on food markets. Thus, poor people become immediately vulnerable to potential price spikes. Urban dwellers buy $90 \%$ of their food from outside. Therefore, food prices are a major determinant of whether food products can be acquired or not (Ruel et al., 2003). The PDS plays a vital role in food management operations, especially in developing countries today. The most important food items covered under the PDS in India are rice, wheat, and sugar. These three items together account for greater percentage of the total PDS sales (Sarkar, 2005). In West Bengal, annual income of all households below $₹ 42,000$ or less was provided with the benefits of ration. Rice is provided at $₹$ two per $\mathrm{kg}$ and flour is provided at $₹$ five per $750 \mathrm{gm}$ by the West Bengal PDS. ${ }^{5}$ Though the government is providing rice at ₹ two per $\mathrm{kg}$, the production cost of rice is much higher and the government pays huge amount of subsidy for running PDS. If urban growth continues to change the agricultural land and affect food production, then how long the state will be able to provide subsidy in PDS is a matter, which needs attention. Often it is found that the rice available at ration shops lacks adequate quality. During the primary survey, it is found that amongst 200 household surveyed, 73 households do not prefer to consume food from fair price shops because of poor quality of grains. 32 households reported that in spite they fall under poverty line they do not get PDS facilities. The amount of grains provided by PDS is also not sufficient to the rural poor as their nutrition is very dependent on this. Thus, they have to avail food from outside (Data Source: Field Survey, 2016).

\footnotetext{
${ }^{5}$ Food Security Made Possible, 2015,http://www.aitcofficial.org/aitc/food-securitymade-possible (accessed September 20 2017)
}

The PDS suffers from several criticism like lower quality of food grains, substantial amount of leakage which affects the third measurement of food security that is food safety. Generally, it is found that in urban areas, food is consumed outside the house. In many developing countries, the set-up of street stalls is unregulated. There is deficiency of adequate refrigeration, water, sanitation and other facilities in the food stalls. Vendors are not often trained in preparing, handling, and storing food safely. Therefore, connection between consumption of street foods and the prevalence of gastrointestinal infections have been detected in developing countries (Maxwell et al., 2000; FAO 2008). Ration commodities are provided only to the people having proper residential address. Homeless, beggars and others who do not have appropriate residential address are left out of this programme in most cases. This fact certainly affects the access of food to all individuals, especially those who do not have any food purchasing capacity (Sarkar, 2005). A definite stride would therefore have to be taken by all the three organs of the country, that is, legislature, executive and judiciary at least to see that food reaches the hungry populace (Sirpurkar, 2015). Some other issues associated with PDS are high cost to run the system, the question of urban biasness, regional disparities in PDS benefits, low amount of procurement, problems of focusing on the needy people, high level of food subsidy, minimal cost-benefit ratio and so on (Sarkar, 2005).

\section{Conclusion}

The objective of the paper was to find out the relationship between urban expansion and reduction of land under agriculture and its effect on the future food security. It is found that there is profound impact of urbanisation on all dimensions of food security in the study area. The study area has experienced rapid pace of urbanisation and infrastructural development within a span of 10 years from 2001 to 2011 . Consequently, the net sown area of the selected blocks has declined and non- 
agricultural landuse has increased simultaneously. Future projection of landuse change, loss of soil fertility, productivity decrease, and rise of population are some of the facts, which are directly consequent upon the future food security of the area.

An important consequence of urbanisation can be establishment of a new balance with the agricultural processes. This new balance necessitates direct attention to a number of problems that must include both formal and informal planning (Winfield, 1973: 73). Lower yield rate, constant increase of population, contraction of cropland by built up area and infrastructural development are the major problems in the study area. To deal with these problems, modern agricultural system becomes important. Modern agricultural process is solely dependent upon several formal and informal planning in agriculture, which requires access to resources, technology, management, investment, markets and supportive government policies. There must be proper supply of nutrients to maintain soil fertility. Plant growth must be promoted without soil loss by new technologies and machineries. Effective irrigation system along with the use of improved genetics for crops and livestock to enhance yields and use of modern genetic and other techniques to protect plants and livestock from losses to competing plants, diseases, drought insects and other threats are necessary actions to be given attention. There must be a highly productive and efficient system that simultaneously protects the environment by means of sensitive and efficient use of natural resources (Motes, 2010: 13). Moreover, balanced urbanisation is a good sustainable urbanisation example where attainment of sustainable food security is must, which involves issues like conserving land, water, and economic growth through food production (Chambers, 1987; Jain et al., 2010 and Liu et al., 2017).

\section{References}

Acharya, S.S., Singh, S. and Vidya Sagar (2002). Sustainable agriculture, Poverty and Food
Security, Volume I, New Jaipur: Rawat Publications (ISBN: 8170337259)

Aldred, D. (2012). Urbanization: A major driver of infrastructure spending, Citi Perspectives, 6, pp.36-39

Atkinson, S. J. (1995). Approaches and actors in urban food security in developing countries, Habitat international, 19(2), pp.151-163

Bajpai, A.D.N. (1995). Linkages between Infrastructure and Economic Development. In Gaur (eds.), New Delhi: Development and Planning, Sarup \& Sons

Baker, W. (1989). A review of models of landscape change, Landscape Ecology, 2, pp. 111-133

Belal, A. A. and Moghanm, F. S. (2011). Detecting urban growth using remote sensing and GIS techniques in Al Gharbiya governorate, Egypt, The Egyptian Journal of Remote Sensing and Space Science, 14(2), pp.73-79

Bell, E. J. and Hinojosa, R. C. (1977). Markov analysis of landuse change: continuous time and stationary processes, Socio-Economic Planning Sciences, 11(1), pp. 13-17

Berdi, C. and Cavinato (1982). Transportation, New York: Western Publishing Company

Bhattacharyya, R., Ghosh, B.N., Mishra, P.K., Mandal, B., Rao, C.S., Sarkar, D., Das, K., Anil, K.S., Lalitha, M., Hati, K.M. and Franzluebbers, A.J. (2015). Soil degradation in India: Challenges and potential solutions, Sustainability, 7(4), pp. 3528-3570

Blum, W.E.H. (1997). Soil degradation caused by industrialization and urbanization, Presented in the International Conference on Problems of Anthropogenic Soil Formation, Moscow, Russia, pp. 1-5

Chakraborty, S., Chatterjee, S., Das, K., \& Roy, U. (2015). Changing Pattern of Urbanization in West Bengal: An Analysis of 2011 Census of India Data, Asian Journal of Research in Social Sciences and Humanities, 5(5), pp. 169-181

Chakraborty, S., Jabbar, Z., Subramanian, L., \& Nyarko, Y. (2016). Satellite image analytics, land change and food security. Paper presented at 
ACM SIGKDD Workshop on Data Science for Food, Energy and Water, co-located with KDD, San Francisco, 2016

Chambers, R. (1987). Sustainable Livelihoods, Environment and Development: Putting Poor Rural People First, Institute of Developmental Studies, pp.1-35

Chen, J. (2007). Rapid urbanization in China: A real challenge to soil protection and food security, Catena, 69, pp. 11-15

Clark, W. A. (1965). Markov chain analysis in geography: an application to the movement of rental housing areas, Annals of the Association of American Geographers, 55(2), pp. 351-359

Dewan, A.M. and Yamaguchi, Y. (2009). Landuse and land cover change in Greater Dhaka, Bangladesh: Using remote sensing to promote sustainable urbanization, Applied Geography, 29(3), pp.390-401

Directorate of Census Operations, 1951-2011. District Census Handbook: Hugli, West Bengal

Dong, W., Zhang, X., Wang, B. and Duan, Z. (2007). Expansion of Ürümqi urban area and its spatial differentiation, Science China, Earth Sciences, 50, pp.159-168

Economic Survey: 2016-17. India, Available at http://www.indiabudget.nic.in/es2000-

01/chap820.pdf(accessed September 20, 2017)

Ekpenyong, A.S. (2015). Urbanization: Its Implication for Sustainable Food Security. Health and Nutritional Nexus in Developing Economies - A Case Study of Nigeria, Journal of Studies in Social Sciences, 11(1), pp. 29-49

El-Raey, M., Nasr, S., El-Hattab, M., Frihy, O. (1995). Change detection of Rosetta promontory over the last forty years, Remote Sensing, 16, pp. 825-834

FAO, (2008). Introduction to the Basic Concepts of Food Security, Food Security Information for Action, Rome, pp.1-3

Food Security Made Possible by the Mamata Banerjee Government: 2015.West Bengal, Available http://www.aitcofficial.org/aitc/food-security- made-possible-by-the-mamata-banerjee-

government/ (accessed $20^{\text {th }}$ Nov 2015)

Ghosh, B., \& Chakma, N. (2014). Urbanisation in West Bengal: An Analysis of Recent Processes, Space and Culture, India, 2(2), pp. 28-41

Government of West Bengal, 2000-01, 2012-13. Blockwise Landuse Classification, Department of Agriculture, West Bengal

Government of West Bengal, 2012. District Statistical Handbook: Hugli, Bureau of Applied Economics and Statistics, Department of Statistics and Programme Implementation, Kolkata

Hauser, P. M. and Duncan, O.D. (1954). The study of Population: An inventory and Appraisal, Chicago: The University of Chicago Press (ISBN: 978-1135160074)

Hegazy, I. R., and Kaloop, M. R. (2015). Monitoring urban growth and landuse change detection with GIS and remote sensing techniques in Daqahlia governorate Egypt, International Journal of Sustainable Built Environment, 4(1), pp. 117-124

Huang, S., Wang, S., and Budd, W. (2009). Sprawl in Taipei's peri-urban zone: Responses to spatial planning and implications for adapting global environmental change, Landscape and urban planning, 90(12), pp. 20-32

Impact Assessment of PMGSY: 2017. Government of India, Available at http://pmgsy.nic.in/pmgi112.aspx (accessed December 16, 2016)

Induced Urbanization, Agricultural Productivity and Poverty Incidence Nexus: A Further Test of Kuznets Hypothesis in Nigeria: 2015. Adesegun, O.M., Olarotimi, R.S., Available at: http://uaps2015. princeton.edu/uploads/15098 7(accessed September 20, 2017)

Islam, M.R. and Hassan, M.Z. (2013). Losses of agricultural land due to infrastructural development: A study on Rajshahi district, Intl. J. Scientific Eng. Res, 4 (11), pp. 391-397 
Jain, P. K., Hansra, B., Chakraborty, K. and Kurup, J.M. (2010). Sustainable food security, New Delhi: Mittal Publications (ISBN: 9788183243568)

Jat, M.K., Garg, P.K. and Khare, D. (2008). Monitoring and modelling of urban sprawl using remote sensing and GIS techniques, International journal of Applied earth Observation and Geoinformation, 10(1), pp. 26-43

Jensen, J.R. (1983). Urban/suburban land-use analysis. In R.N. Colwell. (eds), Manual of Remote Sensing, Virginia, USA: American Society of Photogrammetry, pp. 1571-1666

Karmakar, J. (2015). Emergence of Census Towns and its Socio-Economic Condition: Case of West Bengal, Growth, 6(7.02), pp. 21-03

Kharel, G. (2011). Impacts of urbanization on environmental resources: A landuse planning perspective, University of Texas, Arlington, pp.1-68

Kiran, V.S.S. (2013). Change Detection In Landuse/Landcover Using Remote Sensing \& G.I.S Techniques: A Case Study of Mahananda Catchment, West Bengal, International Journal of Research in Management Studies, 2(2), pp.68-72

Lin, G.C.S., Ho, S.P.S. (2003). China's land resources and land-use change: Insights from the 1996 land survey, Landuse Policy, 20, pp.87-107

Liu, R., Wei, C., Lu, Y. and Hu, Z. (2017). New Balanced Urban-Rural Development for Urbanization in Western China, Presented in the Tenth International Conference on Management Science and Engineering Management, Springer Singapore, pp. 789-801

Marcotullio, P. J., Braimoh, A. K., \& Onishi, T. (2008). The impact of urbanization on soils, In A. K. Braimoh, \& P. L. G. Vlek (eds.), Landuse and soil resources, Springer, pp. 201-250

Martin, L.R.G., Howarth, P.J. (1989). Change detection accuracy assessment using SPOT multispectral imagery of the rural-urban fringe, Remote Sensing Environment, 30, pp.55-66
Massah, J. and Azadegan, B. (2016). Effect of Chemical Fertilizers on Soil Compaction and Degradation, Agricultural Mechanization in Asia, Africa, and Latin America, 47(1), pp. 44-50

Matuschke, I. (2009). Rapid Urbanization and Food Security: using Food Density maps to identify future food security hotspots, Presented in the International Association of Agricultural Economists Conference, Bejing, China, 2009

Maxwell,D., C. Levin, M. Armar-Klemesu, M.Ruel, S.Morris, and C. Ahiadeke. (2000). Urban livelihoods, and food and nutrition security in Greater Accra, Ghana, Washington DC: International Food Policy Research Institute

McGranahan, G., Satterthwaite, D. (2014). Urbanisation concepts and trends, IIED Working Paper, London

Motes, W. (2010). Modern Agriculture and Its Benefits-Trends, Implications and Outlook, Global Harvest Initiative, Washington, D.C.

Mothorpe, C., Hanson, A. and Schnier, k. (2013). The Impact of Interstate Highways on Landuse Conversion, Economics faculty Research and Publications, Marquette University, 51 (3), pp. 833-870

Mukherjee, N. and Siddique, G. (2017). Impact of Urbanization on Agriculture, Presented in National Seminar on Landuse Planning and Management, Organized by Institute of Landscape, Ecology and Ekistics and Department of Geography, University of Calcutta, Kolkata, September 28-29, 2016, pp. 85-90

Mundia, C.N. and Aniya, M. (2006). Dynamics of landuse/cover changes and degradation of Nairobi City, Kenya, Land Degradation \& Development, 17(1), pp. 97-108

Naab, F.Z., Dinye, D.R. and Kasanga, R.K. (2013). Urbanisation and its impact on agricultural lands in growing cities in developing countries: a case study of Tamale in Ghana, Modern Social Science Journal, 2, pp. 256-287

Nayak, P. (1999). Infrastructure: its development and impact on agriculture in 
North-East India, Journal of Assam University,4, pp. 59-65

Padam, S. and Singh, S.K. (2001). Urbanization and Urban Transport in India: The Sketch for a Policy. Presented in Transport Asia Project Workshop, Pune, 2001, pp. 1-27

Pellikka, P., Clark, B., Hurskainen, P., Keskinen, A., Lanne, M., Masalin, K. (2004). Landuse change monitoring applying geographic information systems in the Taita Hill, Se-Kenya, Presented in the 5th African Association of Remote Sensing of Environment Conference, Nairobi, Kenya, 2004, pp. 18-21

Population Projections: Meaning, Types and Importance: 2017. Divisha, S., Available at http://www.sociologydiscussion.com/demogra phy/population-projections/population-

projections-meaning-types-and-

importance/3058 (accessed 20 September 2017)

Ruel, M.T. (2000). Urbanization in Latin America: Constraints and opportunities for child feeding and care, Food and Nutrition Bulletin, 2, pp. 12-24

Sajjad, H. and Iqbal, M. (2012). Impact of urbanization on landuse/land cover of Dudhganga watershed of Kashmir Valley, India, International Journal of Urban Sciences, 16(3), pp. 321-339

Sanchez-Rodriguez, R., Seto, K.C., Simon, D.,Solecki, W.D., Kraas,F., Laumann, G. (2005). Science Plan: Urbanization and global environmental change, Bonn, Germany: IHDP

Sarkar, R.J. (2005). A study of Food Security System in Burdwan District of West Bengal, Department of Economics, University of Burdwan, West Bengal, pp.1-276

Satterthwaite, D., McGranahan, G. and Tacoli, C. (2010). Urbanization and its implications for food and farming, Philosophical Transactions of the Royal Society London, 365, pp. 2809-2820.

Seto, K.C., Kaufmann, R.K. (2003). Modeling the drivers of urban landuse change in the Pearl river delta, China: integrating remote sensing with socioeconomic data, Land Economics, 79, pp.106-122
Sayeed, S. (2014). Urbanization, Food Security and Sustainable Development: A Challenge for Bangladesh, Department of earth Sciences, Uppsala University, pp. 1-46

Shilling, J.D. (2007). The Nexus between infrastructure and environment, Evaluation Cooperation Group, 1, pp. 1-35

Sirpurkar, V.S. (2015). Food and nutritional security for the poor: Role of legislature, Executive and Judiciary, pp. 51-56

Szabo, S. (2016). Urbanisation and Food Insecurity Risks: Assessing the Role of Human Development, Oxford Development Studies, 44(1), pp. 28-48

Tetsuji, T.A.N.A.K.A. and Nobuhiro, H.O.S.O.E. (2009). Productivity shocks and national food security for Japan, The Research Institute of Economy, Trade and Industry, pp. 1-62

Urbanization: Problems and Solutions, International Islamic University Malaysia: 2016. Omer, S., Available at https://scholar.google.co.in/scholar?hl=en\&q= NUR+NABILA+AHMAD+AZAM\%2C+urbanization + problems+and+solutions \&btnG (accessed September 20, 2017)

Weber, C., Puissant, A. (2003). Urbanization pressure and modeling of urban growth: example of the Tunis Metropolitan Area, Remote Sens. Environ, 86, pp. 341-352

Wei, Y.D. (2007). Regional development in China: transitional institutions, embedded globalization, and hybrid economies, Eurasian Geography and Economics, 48(1), pp. 16-36

Winfield, G.F. (1973). The Impact of Urbanization on Agricultural Processes, The Annals of the American Academy, 405(1), pp. 65-74

World Disasters Report 2010, Focus on urban risk. Geneva: The International Federation of Red Cross and Red Crescent Societies (IFRC): 2010. International Federation of Red Cross and Red Crescent Societies, Available at https://www.ifrc.org/Global/Publications/disas ters/WDR/WDR2010-full.pdf

(accessed

September 20, 2017) 
Xie, Y., Yu, M., Bai, Y. and Xing, X. (2006). Ecological analysis of an emerging urban landscape pattern-desakota: a case study in Suzhou, China, Landscape ecology, 21(8), pp.1297-1309

Yang, H., Li, X. (2000). Cultivated land and food supply in China, Landuse Policy, 17, pp.73-88

Yeh, A.G.O. and Li, X. (1999). Economic development and agricultural land loss in the Pearl River Delta, China, Habitat international, 23(3), pp. 373-390

Yin, J., Yin, Z., Zhong, H., Xu, S., Hu, X., Wang, J. and $\mathrm{Wu}$, J. (2011). Monitoring urban expansion and landuse/land cover changes of Shanghai metropolitan area during the transitional economy (1979-2009) in China, Environmental monitoring and assessment, 177(1), pp. 609621

Zhang, X., Mount, D.T., Boisvert, R.N. (2004). Industrialization, urbanization and landuse in China, Journal of Chinese Economic and Business Studies, 2 (3), pp. 207-224

\section{Acknowledgements}

We are immensely thankful to Avipsita Chatterjee, Senior Research Fellow, Department of Applied Mathamatics, University of Calcutta for helping us with Markov Chain Model. Equally, we are thankful to Rahaman Ashique Ilahi, Project Fellow, Department of Geography, The University of Burdwan for providing necessary help in Remote Sensing and GIS. We also thank the anonymous reviewers and the editor for their valuable comments and assistance in improvement of the paper.

\section{About the Authors}

Professor Giyasuddin Siddique has been working in the Department of Geography, the University of Burdwan, since 1999. He acquired his Masters degree in Geography in 1983 and Ph.D degree in 1999 from the same University. The title of his thesis was "Impact of Deforestation in Parts of South-Western Lateritic Areas of West Bengal". He has more than 40 research papers published in various esteemed National and International Journals and he has also written six textbooks. Six scholars have been awarded Ph.D degree under his supervision and three theses have been already submitted for examination. Another seven scholars are currently working under his guidance for the fulfilment of Ph.D degree. Professor Siddique has more than 25 years' experience of field based research on forests, tribal culture, human ecology, social environmental problems, river dams, hazard studies, gender issues, human development, quality of life, etc.

Nabanita Mukherjee is currently working as a UGC-Junior Research Fellow (Ph.D Scholar) in the Department of Geography, the University of Burdwan since 2015. She completed M.Sc. from Department of Geography, University of Calcutta. She has two research paper published in International Journals and two chapters in edited books. She has research interest in the studies of climate change, sustainable development, urbanisation, landuse/land cover change and various other issues. 